\title{
ENGLISH TEACHERS' PERCEPTIONS TO AUTHENTIC ASSESSMENT
}

\author{
Rohib Adrianto Sangia
}

\begin{abstract}
Authentic assessment is a meaningful measurement significantly over the study of students to the domain of attitudes, knowledge, and skills. In applying authentic assessment to determine the learning outcomes of students, teachers apply the criteria relating to the construction of knowledge, and try to observe activity, and value beyond school achievement. The purpose of this authentic assessment is to measure a variety of skills in a variety of contexts that reflect real-world situations where those skills are used. The types of authentic assessment in the curriculum in 2013 include performance assessment, portfolio assessment, project assessment, and a written assessment. Stages in authentic assessment in the 2013 curriculum are included analysing core competencies and basic competence. Basic competence determines the appropriate foundation to learning, to develop indicators of basic competencies chosen, and determining aspects, forms, rubrics, and assessment instruments. In order to implement effective authentic assessment the teacher must clearly understand the objectives to be achieved. This research has purposed to expose the response from the language teachers in Ambon after having curriculum 2013 training. The results show the teachers are grouped into two major opinions, the optimistic and pessimistic teachers.
\end{abstract}

Keywords: authentic assessment, assessment types, teachers' perception.

\section{INTRODUCTION}

Authentic assessment is a form of task that requires learners to demonstrate real-world performance significantly essence of which is the application of knowledge and skills (Reyes and Vallone, 2008: 59). Authentic assessment emphasizes the learner's ability to demonstrate knowledge in a real and meaningful. Assessment activities not just ask or tapping the knowledge that has been known to the learner, but the real performance of the knowledge that has been mastered. The purpose of this assessment is to measure a variety of skills in a variety of contexts that reflect realworld situations where those skills are used. For example, the assignment to the learner to read a variety of actual text-realistic, write certain topics as well as in real life, and participate in the discussion concrete or book review, writing for journals, letters, or edit the text to print ready. In this activity, both learning and assessment materials or even indeed a natural look. Thus, this model emphasizes the assessment of 
performance measurement, doing something, doing something which is the application of science who has mastered theoretically.

Authentic assessment is a meaningful measurement significantly over the study of students to the domain of attitudes, skills, and knowledge. Wiggins (1999: 51) defines authentic assessment as efforts to provide assignments to students who reflect the priorities and challenges found in learning activities, such as researching, writing, revising, and discussing the article, giving oral analysis of the events, collaborate through debate and so on. Mueller (In Williams, Hricko, and Howell, 2006: 242) defines authentic assessment is a form of assessment in which students are asked to perform tasks that demonstrate Real-world meaningful application of essential knowledge and skills.

Stiggins (1997: 206) defines authentic performance assessment as assessment that asks the learner to demonstrate certain skills and competencies which is the application of knowledge under their control. Conceptually authentic assessment was statistically significant compared to multiple choice standardized tests once. When applying authentic assessment to determine learning outcomes and achievement of students, teachers apply the criteria relating to the construction of knowledge; try to observe activity and value beyond school achievement.

The alternative types (not-techniques) of authentic assessment in the curriculum in 2013 are performance assessment, project assessment, portfolio assessment, and a written assessment (Kementerian Pendidikan Dan Kebudayaan, 2013). First performance assessment, teacher can do so by having participants mentioned elements task will use to determine the criteria for its solution. By using this information, the teacher can provide feedback on the performance of learners in the form of a narrative report or report class. How to record the results of the performance-based assessment with a check list, notes anecdotal / narrative, rating scale, and memory.

Assessment of performance requires special considerations, explicitly a) the performance measures should be learners to demonstrate the real performance for some types of specific competencies; b) the accuracy and completeness of the assessed aspects of performance; c) special abilities learners are required to complete the learning tasks; d) The main focus of the performance indicators that will be assessed particularly essential to be observed; e) the order of abilities or skills that learners will be observed.

To assess language skills of learners, from the aspect of speaking skills such as speech teachers can observe, discuss storytelling and interviews. To observe the 
performance of learners can use assessment tools or instruments such as attitude, behaviour observation, direct questions, or personal questions.

Secondly, the project assessment is the assessment of the tasks to be completed by students by period / specific time. Completion of the task is in the form of an investigation carried out by learners ranging from planning, data collection, organization, processing, analysis, and data presentation. Three things to consider in the assessment of teachers is a project) skills of learners in choosing a topic, searching and collecting data, processing and analysing, give meaning to the information obtained, and write reports; b) the suitability or relevance to the development of learning materials attitudes, skills, and knowledge needed by learners; c) the authenticity of a learning project undertaken or produced by learners.

Assessment of the project focuses on the planning, construction, and project products. Project assessment instruments can use the check list, rating scale, or narrative. The assessment report can be poured in the form of posters or writing. The final product of a project intended to assess the quality and shape of the final outcome holistically and analytically.

Third is portfolio assessment. It is an assessment of the collection of artefacts that show progress and appreciated the work of the real world. Portfolio assessment can depart from the work students produced individually or in groups, learners require reflection, and evaluated based on several dimensions. Portfolio assessment is continuous assessment based on the collection of information that shows the development of the ability of learners in a given period.

Portfolio assessment is done by using the steps that a) the teacher briefly describes the essence of portfolio assessment; b) the teacher or the teacher with the students determine the type of portfolio to be created; c) learners, either individually or groups, independently or under the guidance of teachers prepare learning portfolio; d) teachers collect and store portfolio learners at the appropriate place along with the record date of collection; e) teachers assess student portfolios with certain criteria; f) if possible, the teacher with the students to discuss with a portfolio of documents produced; g) the teacher gives feedback to learners on the assessment portfolio.

Fourth is the written assessment. It is an assessment in the form of a written description or essay that requires students are able to remember, understand, organize, implement, analyse, synthesize, evaluate, and so on material already learned. The written test form is comprehensive explanation as possible so as to describe the domain of attitudes, knowledge, and skills of students. 
In the form of an essay written test, students had the opportunity to give answers that differ from his friends. But it remains open to obtain the same value. The form of an essay written test usually requires two types of pattern of response that is open or restricted. It really depends on the weight problem given by the teacher. Such a test gives teachers the opportunity to be able to measure the learning outcomes of students at a higher level or complex.

\section{METHOD}

In this study, researchers used a qualitative approach. Qualitative approach produces approach and process data that are descriptive, such as transcription of interviews, records and reports etc. (Bishop-Clark and Dietz-Uhler, 2012: 86). According to Creswell (2013: 47), qualitative research is a research process to understand the problem - human or social problem by creating a comprehensive and complex picture is presented in words, reporting detailed views of informants, and conducted in the natural setting.

The data collection technique in this research is using open interview method. An interview is a conversation with a purpose. The conversation was conducted by the two parties, namely the interviewer and interviewee (Packer, 2011: 51). The subjects were English teachers MAN Ambon who voluntarily participate. To obtain research subjects, researchers came up to them during the academic workshop on February 16 to July 18, 2014 in the Multimedia Room MAN Ambon.

\section{RESULT AND DISCUSSION}

From the open-interview with the teachers, the condition shows 50\% per cent of teachers are enthusiastic with the curriculum development from curriculum 2006 to curriculum 2013. All of the teachers felt better by knowing that government has complemented the teaching administration and all that teachers should do is writing lesson plan. The fact showed that socialization of curriculum 2013 had not reached optimum results especially for the teacher of madrasah because they are under bow of Ministry of Religious Affairs which practically starts curriculum 2013 in 2014 not like Institutions or schools under Education Ministry.

After joining the academic workshop, teachers $75 \%$ teachers showed pessimistic attitude of the type and technique authentic assessment from curriculum 2013. Most of them are senior teachers, senior in working hours, who objected with the newest assessments. There are some reasons was exposed by them. 
The first reason that they believe was the type are too many. It means teachers should prepare not only various materials to teach but also various materials to test with various way of assessing. They will spend teachers' energy in creating the test and need more time. This analysis clearly shows the teachers behaviour that they don't want to work hard. Less of dedication to education makes them lazy to accept the changes, while everything will changes.

The second reason is the teachers felt not confidence to their students. They sensed students will get much pressure to do anything in getting the mark. Students psychologically are pressed with many assignments from teachers which not only spend their time but also expend their energy.

The rest $25 \%$ of teachers are optimist to the authentic assessments. They seemed to be dedicated teachers which always prepare to the changes and optimist in works. Most of them are young teacher who are open-minded. They were positivethinking to system, and they believe that the authentic assessment not only will change the students' behaviour but also the teacher themselves. They also gave counteropinion to the previous teachers.

\section{CONCLUSION}

An authentic assessment gives students' chance in having cognitive, psychomotor, and attitude evaluations. It is authentic because it involves various ways in measuring the students. It can be concluded that authentic assessments is not apart with the learning activities, but it occasionally has function in make things easier for both teachers and students.

The assessment in Curriculum 2013 showed the progressive approach in measuring student's skills. Instead of offering only paper and pencil test with large number of items separated, language performance-based assessment usually involves oral production, written production, open response, performance of the integrated skills, the performance of the group, and other interactive tasks. To be sure, the assessment is time consuming and therefore expensive, but the extra efforts resulted in a more direct test for students assessed as they perform real-world tasks actual or simulated. In shorts, a higher content validity is achieved by making learners measured in the targeted linguistic act (Brown, 2004: 11). 


\section{REFERENCES}

Bishop-Clark, Cathy, and Dietz-Uhler, Beth. 2012. Engaging in the scholarship of teaching and learning : a guide to the process, and how to develop a project from start to finish.

Brown, H. Douglas. 2004. Language assessment : principles and classroom practices. London: Longman.

Creswell, John W. 2013. Qualitative Inquiry \& Research Design : Choosing Among Five Approaches. Los Angeles: Sage.

Kementerian Pendidikan Dan Kebudayaan. (2013). Lampiran IV Permendikbud Nomor 81A Tentang Pedoman Umum Pembelajaran. Jakarta: Kementerian Pendidikan Dan Kebudayaan.

Packer, Martin J. 2011. The science of qualitative research. New York: Cambridge University Press.

Reyes, Sharon Adelman, and Vallone, Trina Lynn. 2008. Constructivist strategies for teaching English language learners. Thousand Oaks, CA: Corwin Press.

Stiggins, Richard J. 1997. Student-centered classroom assessment. Columbus, Ohio: Merrill.

Wiggins, Grant P. 1999. Assessing student performance : exploring the purpose and limits of testing. San Francisco: Jossey-Bass Publishers.

Williams, David D, Hricko, Mary, and Howell, Scott L. 2006. Online assessment, measurement, and evaluation : emerging practices. Hershey, PA: Information Science Pub. 